\title{
Microstructure and Corrosion Behavior of Friction Stir-Welded 6061 Al/AZ31 Mg Joints with a Zr Interlayer
}

\author{
Yang Zheng ${ }^{1, * \mathbb{C}}$, Xiaomeng Pan ${ }^{2}$, Yinglei Ma ${ }^{1}$, Shuming Liu ${ }^{3}$, Libin Zang ${ }^{1}$ and Yong Chen ${ }^{1, *}$ \\ 1 School of Mechanical Engineering, Hebei University of Technology, Tianjin 300130, China; \\ 201821202041@stu.hebut.edu.cn (Y.M.); 201611201012@stu.hebut.edu.cn (L.Z.) \\ 2 Patent Examination Cooperation (Tianjin) Center of the Patent Office, CNIPA, Tianjin 300304, China; \\ pan_xi_aomeng@126.com \\ 3 School of Chemical Engineering and Technology, Hebei University of Technology, Tianjin 300130, China; \\ 1sm9707@163.com \\ * Correspondence: zhengyang@hebut.edu.cn (Y.Z.); chenyong@hebut.edu.cn (Y.C.)
}

Received: 17 March 2019; Accepted: 1 April 2019; Published: 3 April 2019

check for updates

\begin{abstract}
Friction stir welding (FSW) with a $\mathrm{Zr}$ interlayer was employed to join dissimilar alloys of $6061 \mathrm{Al}$ and $\mathrm{AZ} 31 \mathrm{Mg}$. The microstructures of $\mathrm{Al} / \mathrm{Mg}$ and $\mathrm{Al} / \mathrm{Zr} / \mathrm{Mg}$ joints were investigated by optical microscopy (OM), scanning electron microscopy (SEM), and energy dispersive $\mathrm{X}$-ray spectrometer (EDS). The results showed that the central part of the $\mathrm{Zr}$ interlayer was smashed and intermixed with the base materials in the stir zone, whereas the undamaged part remained stable at the $\mathrm{Al} / \mathrm{Mg}$ interface. The formation of $\mathrm{Al}-\mathrm{Mg}$ intermetallic compounds (IMCs) was suppressed by the $\mathrm{Zr}$ interlayer due to its synergetic effects of chemical modification and thermal barrier. The electrochemical measurements revealed a differentiated corrosion behavior for each joint, where the corrosion rate of representative regions increased in the order of $\mathrm{Al}$ alloy $<\mathrm{Mg}$ alloy $<$ heat-affected zone < stir zone. The immersion tests indicated an enhancement in corrosion resistance for the $\mathrm{Al} / \mathrm{Zr} / \mathrm{Mg}$ joint compared with the $\mathrm{Al} / \mathrm{Mg}$ joint, which is owing to the mitigated galvanic corrosion between the base materials by the $\mathrm{Zr}$ interlayer.
\end{abstract}

Keywords: friction stir welding; $\mathrm{Al} / \mathrm{Mg}$ dissimilar joints; $\mathrm{Zr}$ interlayer; corrosion; microstructure

\section{Introduction}

Vehicle weight reduction is attracting unprecedented attention under increasingly strict emission regulations in recent years. $\mathrm{Al}$ and $\mathrm{Mg}$ alloys have been extensively studied to substitute steel parts to realize an obvious lightweight effect. The development of suitable welding techniques for these two alloys is vital and has become a hot research topic [1,2]. However, the undesirable $\mathrm{Al}-\mathrm{Mg}$ intermetallic compounds (IMCs) with hard and brittle properties formed by the conventional fusion welding techniques seriously deteriorate the joint quality, which is the main obstacle for the dissimilar joining of $\mathrm{Al}$ and $\mathrm{Mg}$ alloys [3,4].

Friction stir welding (FSW), a solid-state welding technique developed by the Welding Institute (Cambridge, UK) in 1991, exhibits great potential to join $\mathrm{Al}$ and $\mathrm{Mg}$ dissimilar alloys [5-8]. Rao et al. [5] demonstrated the feasibility of FSW in joining $6022 \mathrm{Al}$ and AM60B Mg alloys. A sound $\mathrm{Al} / \mathrm{Mg}$ joint with a high failure load was obtained by FSW via building a favorable weld geometry and dispersed Al-Mg IMCs in the stir zone. The studies of Sato et al. [7] and Kostka et al. [8] showed that the formation of $\mathrm{Al}-\mathrm{Mg}$ IMCs, such as $\mathrm{Al}_{3} \mathrm{Mg}_{2}$ and $\mathrm{Al}_{12} \mathrm{Mg}_{17}$ phases, can hardly be avoided owing to the constitutional liquation phenomenon. 
Various kinds of interlayers (including adhesive, pure metal, alloy, and oxide) have been introduced into $\mathrm{Al} / \mathrm{Mg}$ FSW joints to improve their mechanical properties via reducing the $\mathrm{Al}-\mathrm{Mg}$ IMCs [9-12]. For example, Chowdhury et al. [9] added a Terokal 5089 interlayer into the $5754 \mathrm{Al} / \mathrm{AZ31B}$ Mg FSW joint and found a significant enhancement in the lap shear strength and fatigue properties due to the lower amount of Al-Mg IMCs. Xu et al. [10] increased the failure load of a $2024 \mathrm{Al} / \mathrm{AZ} 31 \mathrm{Mg}$ FSW joint by depositing a hot-dipped $\mathrm{Zn}$ interlayer, which was ascribed to the beneficial microstructure of a brazed zone at the shoulder edge (composed of $\mathrm{Mg}-\mathrm{Zn}$ and $\mathrm{Al}-\mathrm{Zn}$ ) and a transition zone in the hook region (constituted with $\mathrm{MgZn}_{2}, \mathrm{Zn}$-rich phase, and residual $\mathrm{Zn}$ ) instead of the Al-Mg IMCs. Gao et al. [12] reported that the plasma electrolytic oxidation (PEO) interlayer could suppress the formation of Al-Mg IMCs and increase the fracture load of an ADC12 Al/AMX602 Mg FSW joint by mitigating the $\mathrm{Al} / \mathrm{Mg}$ interfacial reaction under proper welding parameters.

The research emphasis at present relating to $\mathrm{Al} / \mathrm{Mg}$ FSW joints with interlayers is focused on the enhancement of the mechanical properties. In addition to the mechanical properties, corrosion properties are another key issue for joint safety in the service course $[13,14]$. In general, preferential corrosion occurs at the $\mathrm{Mg}$ alloy in $\mathrm{Al} / \mathrm{Mg} \mathrm{FSW}$ joints because of its lower corrosion potential, which will damage the joint strength and lead to joint failure, compared with that of the Al alloy $[15,16]$. Therefore, it is necessary to regulate the corrosion behavior of $\mathrm{Al} / \mathrm{Mg}$ FSW joints to improve the service performance. However, there is little research on the corrosion behavior of $\mathrm{Al} / \mathrm{Mg}$ FSW joints modified by interlayers. It is known that $\mathrm{Zr}$ has high thermal stability and can act as a barrier layer to mitigate the strong reaction at the $\mathrm{Al} / \mathrm{Mg}$ interface. Moreover, $\mathrm{Zr}$ is an effective grain refinement element for both $\mathrm{Al}$ and $\mathrm{Mg}$ alloys, which can simultaneously improve their mechanical and corrosion properties. Considering the beneficial effects of $\mathrm{Zr}$ on $\mathrm{Al}$ and $\mathrm{Mg}$ alloys, the corrosion behavior of $\mathrm{Al} / \mathrm{Mg}$ FSW joints may be improved by a $\mathrm{Zr}$ interlayer via microstructure optimization. To our knowledge, there are few studies on the preparation and characterization of $\mathrm{Al} / \mathrm{Mg}$ FSW joints with a $\mathrm{Zr}$ interlayer. In this work, the microstructure and corrosion behavior of $6061 \mathrm{Al} / \mathrm{AZ31} \mathrm{Mg}$ FSW joints with a Zr interlayer was investigated. The results can reveal the effects of a $\mathrm{Zr}$ interlayer on the microstructure and corrosion behavior of $\mathrm{Al} / \mathrm{Mg}$ FSW joints, which may provide design guidelines for improving joint corrosion properties by means of interlayers.

\section{Materials and Methods}

\subsection{Materials Pretreatment}

This study used $6061 \mathrm{Al}$ and AZ31 Mg alloys with a size of $300 \mathrm{~mm} \times 60 \mathrm{~mm} \times 3 \mathrm{~mm}$, provided by the Southwest Aluminum (Group) Co., Ltd (Chongqing, China). The corresponding chemical compositions are listed in Table 1. The $0.2 \mathrm{~mm}$-thick $\mathrm{Zr}$ foil (99.9\%), purchased from the General Research Institute for Nonferrous Metals of China, was selected as the interlayer. Before FSW, the base materials were mechanically polished using SiC emery papers with 500, 1000, 1500, 2000, and 3000 grits and ultrasonically cleaned in absolute ethanol.

Table 1. Chemical compositions (in wt.\%) of the $6061 \mathrm{Al}$ and AZ31 Mg alloys.

\begin{tabular}{ccccccccccc}
\hline Materials & Al & Mg & Si & Fe & $\mathbf{C u}$ & $\mathbf{C r}$ & $\mathbf{M n}$ & $\mathbf{Z n}$ & $\mathbf{T i}$ & $\mathbf{N i}$ \\
\hline 6061 & Bal. & 1.00 & 0.73 & 0.30 & 0.28 & 0.16 & 0.05 & 0.05 & 0.01 & - \\
AZ31 & 3.20 & Bal. & 0.05 & 0.0022 & 0.0018 & - & 0.35 & 0.82 & - & 0.00016 \\
\hline
\end{tabular}

\subsection{FSW Process}

The $6061 \mathrm{Al}$ alloy was lap joined to the AZ31 Mg alloy using a SCB-LM2217-2D-3T FSW machine (Beijing Sooncable Technology Development Co., Ltd., Beijing, China). The joint configuration with an overlap area of $300 \mathrm{~mm} \times 50 \mathrm{~mm}$ was arranged as the AZ31 Mg alloy, the Zr interlayer, and the $6061 \mathrm{Al}$ alloy from bottom to top, respectively. The size of the $\mathrm{Zr}$ interlayer was set as $300 \mathrm{~mm} \times 50 \mathrm{~mm} \times 0.2 \mathrm{~mm}$. Figure 1 shows the schematic diagrams of the FSW tool and welding 
process. The FSW tool was composed of a dual-loop shoulder (12 $\mathrm{mm}$ in diameter) and a conical pin with threaded grooves (5 $\mathrm{mm}$ in length and $3 \mathrm{~mm}$ in root diameter). During FSW, the tool rotated anticlockwise and proceeded along the rolling direction (RD) with a tilt angle of $3^{\circ}$ relative to the normal direction (ND). The shoulder plunge depth, rotation rate, and welding speed were $0.2 \mathrm{~mm}$, $800 \mathrm{rpm}$, and $100 \mathrm{~mm} / \mathrm{min}$, respectively.
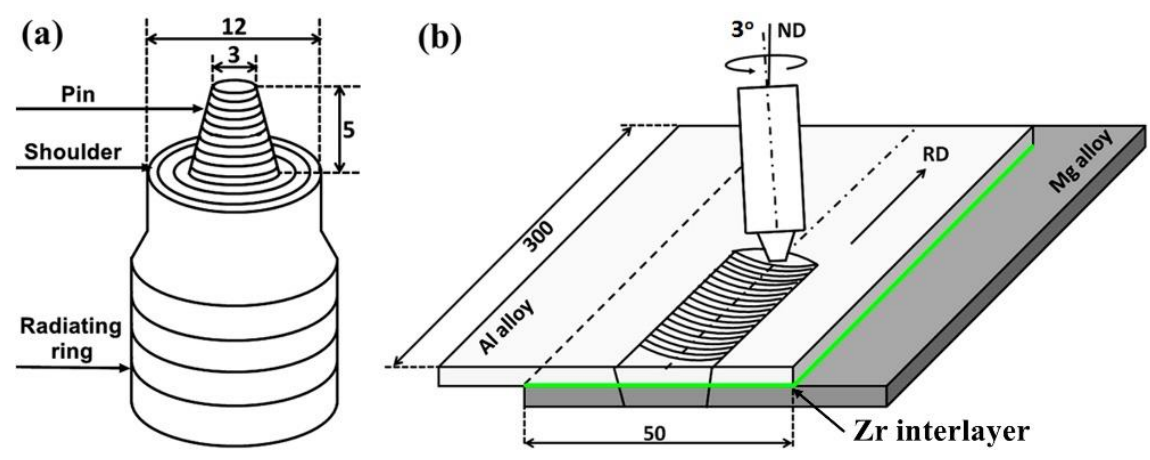

Figure 1. Schematic diagrams of (a) the friction stir welding (FSW) tool and (b) the welding process.

\subsection{Microstructure Characterization}

The joint appearances were captured by a Nikon D7200 digital camera (Bangkok, Thailand). The cross-sectional samples were cut into proper sizes by an electro-discharge machine and mechanically polished to mirror-like surfaces. The etching solutions were $20 \mathrm{~g}$ of $\mathrm{NaOH}$ with $100 \mathrm{~mL}$ of distilled water for $\mathrm{Al}$ alloy and $4 \% \mathrm{HNO}_{3}$ ethanol for $\mathrm{Mg}$ alloy. The macroscopic morphologies were observed by the optical microscopy (OM, DSX-510, Olympus, Tokyo, Japan). The microstructures and chemical compositions were investigated via scanning electron microscopy (SEM, JSM 6480, JEOL, Tokyo, Japan) and energy dispersive X-ray spectrometer (EDS, Oxford Instruments, Abingdon, UK) in the secondary electron mode.

\subsection{Electrochemical Measurements}

The electrochemical measurements were conducted by an electrochemical workstation (CHI-660e, $\mathrm{CH}$ Instruments Inc., Shanghai, China) in $3.5 \% \mathrm{NaCl}$ solution at $25{ }^{\circ} \mathrm{C}$. A three-electrode system with the samples as the working electrode, the saturated calomel electrode (SCE) as the reference electrode, and the platinum sheet as the counter electrode was employed. The FSW joints exhibited characteristic microstructures with four typical regions: the base material (BM), the heat-affected zone (HAZ), the thermo-mechanically affected zone (TMAZ), and the stir zone (SZ) $[17,18]$. Three representative regions of BM, HAZ, and SZ of the FSW joints were tested with no particular attempt to discriminate the HAZ and TMAZ because of their indistinct boundary [19]. The testing areas were exposed with the other areas sealed by the chloroprene rubber. The open circuit potential $(\mathrm{OCP})$ curves were recorded at a sample interval of $0.1 \mathrm{~s}$ for $30 \mathrm{~min}$ to achieve stabilization at the surface/solution interface. The potentiodynamic polarization curves were measured at a scan rate of $1 \mathrm{mV} \cdot \mathrm{s}^{-1}$. The corrosion current density $\left(i_{\text {corr }}\right)$ was calculated in the Tafel linear region by the CHI-660e software at $60 \mathrm{mV}$ relative to the corrosion potential $\left(\mathrm{E}_{\text {corr }}\right)$. Three measurements from each group were taken to calculate the average.

\subsection{Immersion Tests}

Immersion tests were performed in the $3.5 \% \mathrm{NaCl}$ solution at $25^{\circ} \mathrm{C}$ to investigate the changes in corrosion morphologies and corrosion products. After specific immersion times, the samples were taken out, rinsed with distilled water, and dried in air. The corrosion products were analyzed by X-ray diffractometer (XRD, D8 Advance, Bruker, Karlsruhe, Germany) using $\mathrm{Cu} \mathrm{k}_{\alpha}$ radiation in the $2 \theta$ range of $10-90^{\circ}$ at a scan rate of $6^{\circ} / \mathrm{min}$. The corroded surfaces were analyzed by SEM (Quanta 450 FEG, FEI, 
Hillsboro, OR, USA) and its EDS attachment. The weight losses of joints were measured with a scale ( $0.01 \mathrm{mg}$ in accuracy) after removing the corrosion products using the $200 \mathrm{~g} \cdot \mathrm{L}^{-1} \mathrm{CrO}_{3}$ solution.

\section{Results and Discussion}

\subsection{Weld Appearances and Macrostructures}

Figure 2 shows the surface appearances of the $\mathrm{Al} / \mathrm{Mg}$ and $\mathrm{Al} / \mathrm{Zr} / \mathrm{Mg}$ joints. In Figure $2 \mathrm{a}$, the surface of the $\mathrm{Al} / \mathrm{Mg}$ joint is featured by obvious flashes on the weld edges. These flashes are produced in the excreting course of deformed materials from the joint to the surface [20,21]. The $\mathrm{Al} / \mathrm{Zr} / \mathrm{Mg}$ joint has a relatively smooth surface with small flashes, as shown in Figure $2 b$. Homogeneous arc corrugations are observed for both joints, which are formed by the frictional interaction between the rotating tool shoulder and the material surface. Typical keyholes are also generated at the end of the welds as the tool pin retracts from the joint.
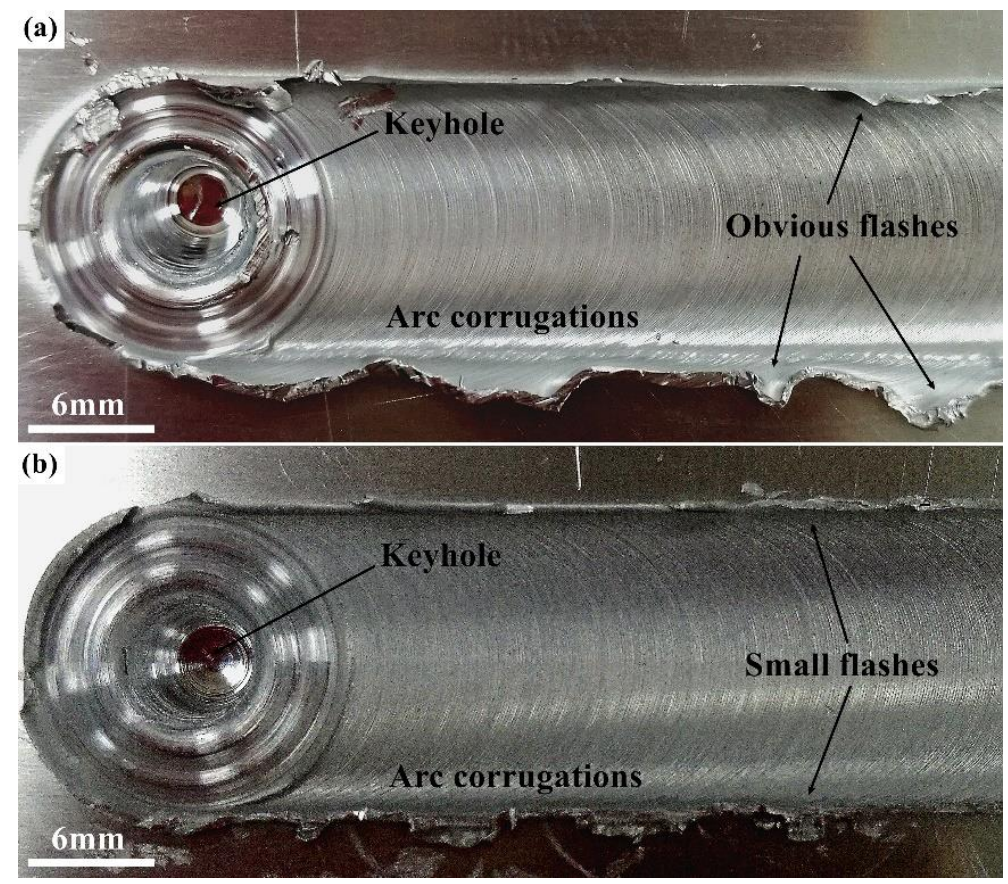

Figure 2. Surface appearances of (a) $\mathrm{Al} / \mathrm{Mg}$ and (b) $\mathrm{Al} / \mathrm{Zr} / \mathrm{Mg}$ joints.

Figure 3 presents the cross-sectional profiles of the $\mathrm{Al} / \mathrm{Mg}$ and $\mathrm{Al} / \mathrm{Zr} / \mathrm{Mg}$ joints. As shown in Figure $3 \mathrm{a}$, the $\mathrm{Al} / \mathrm{Mg}$ joint was developed via the mutual movements of the base materials assisted by the tool pin, which formed a cone-shape $\mathrm{SZ}$ to interlock the $\mathrm{Al}$ and $\mathrm{Mg}$ alloys. For the $\mathrm{Al} / \mathrm{Zr} / \mathrm{Mg}$ joint, as shown in Figure 3b, the central part of the Zr interlayer was stirred into the SZ by the tool pin with the undamaged part being sandwiched at the $\mathrm{Al} / \mathrm{Mg}$ interface. The $\mathrm{SZ}$ of both joints exhibited a non-symmetric structure with the advancing side (AS) showing a steeper edge than the retreating side (RS), which was due to the more severe material flows on the AS [22]. It is noted that some cavity defects were observed at the interface between the SZ and the $\mathrm{Mg}$ alloy for both joints, which may have been caused by the insufficient frictional heat and low deformability of the Mg alloy [5,23]. These cavities are harmful for the joint quality and will be reduced via optimization of the rotation rate and welding speed in the future work. 

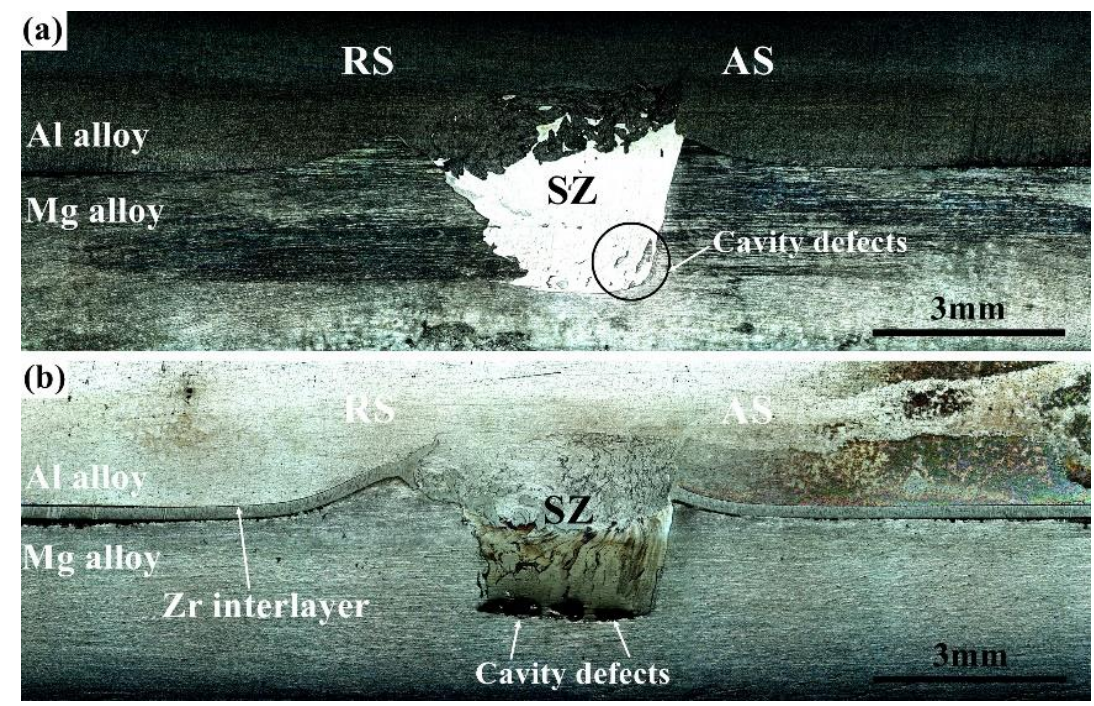

Figure 3. Cross-sectional profiles of the (a) $\mathrm{Al} / \mathrm{Mg}$ and (b) $\mathrm{Al} / \mathrm{Zr} / \mathrm{Mg}$ joints.

\subsection{Microstructures}

Figure 4 depicts the representative microstructures and EDS line-scan results of the $\mathrm{Al} / \mathrm{Mg}$ joint. In Figure $4 \mathrm{a}$, the $\mathrm{SZ}$ of the $\mathrm{Al} / \mathrm{Mg}$ joint is constituted by a chaotic morphology on the top and a uniform morphology on the bottom. The magnified view of the $\mathrm{R} 1$ region in Figure $4 \mathrm{~b}$ reveals the existence of vortex-like Al-Mg IMCs in the SZ. The elemental compositions at points 1-3 in Figure $4 \mathrm{~b}$ are listed in Table 2. The gray zone, dark zone, and white zone, marked as points 1, 2, and 3 are primarily $\mathrm{Al}_{3} \mathrm{Mg}_{2}$, an $\mathrm{Al}$ matrix with little $\mathrm{Al}_{2} \mathrm{O}_{3}$, and $\mathrm{Al}_{12} \mathrm{Mg}_{17}$ with a lot of $\mathrm{Al}_{2} \mathrm{O}_{3}$ and $\mathrm{MgO}$, respectively. Similar results can also be found in other studies of $\mathrm{Al} / \mathrm{Mg}$ FSW joints [24,25]. The detection of metallic oxides may have originated from two sources [26]: (1) the thermal interaction between oxygen and the base materials and (2) the remaining oxide layers on the base materials, which were mixed into the SZ. The magnified view of the R2 region in Figure 4c exhibits an intercalated microstructure with a wide transition zone at the Mg alloy/SZ interface. The magnified view of the R3 region in Figure 4d indicates that there existed a lot of irregular Al-Mg IMCs in the transition zone. The corresponding EDS line-scan results in Figure $4 \mathrm{e}$ show the formation of abrupt changes in elemental contents of $\mathrm{Al}$ and $\mathrm{Mg}$ between adjacent plateaus, suggesting the presence of stable Al-Mg IMCs. The Al-Mg IMCs were formed by the constitutional liquation phenomenon via the eutectic reactions of $\mathrm{L}=\mathrm{Al}+\mathrm{Al}_{3} \mathrm{Mg}_{2}$ at $450{ }^{\circ} \mathrm{C}$ and $\mathrm{L}=\mathrm{Mg}+\mathrm{Al}_{12} \mathrm{Mg}_{17}$ at $437^{\circ} \mathrm{C}$, respectively [27-29]. 

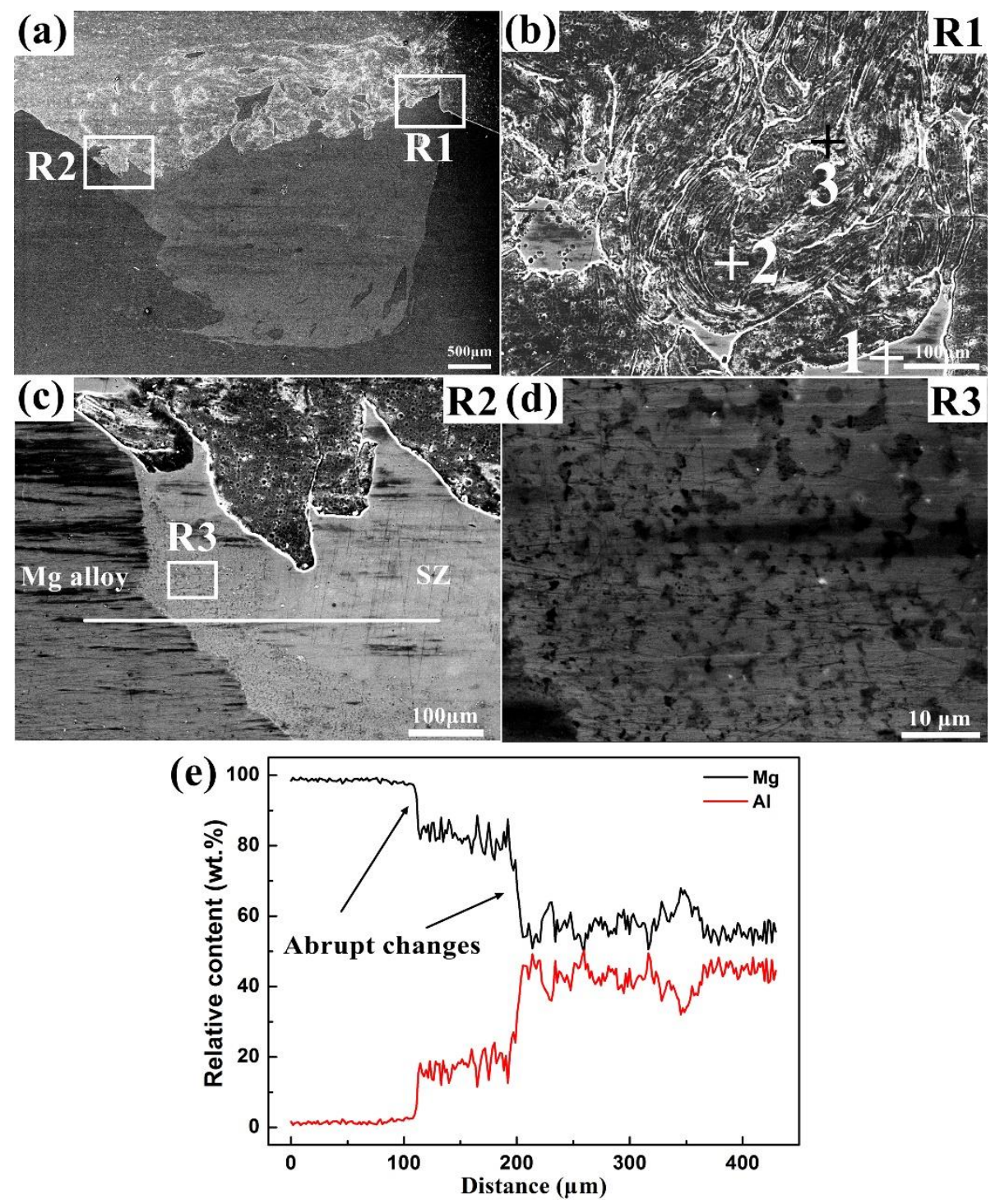

Figure 4. Representative microstructures of the $\mathrm{Al} / \mathrm{Mg}$ joint: (a) overview of the $\mathrm{SZ}$, (b-d) magnified views of the R1, R2, and R3, respectively, and (e) EDS line-scan results of the R2.

Table 2. Elemental compositions (in wt.\%) at points 1-3 in Figure 4b.

\begin{tabular}{cccccc}
\hline Points & $\mathbf{A l}$ & $\mathbf{M g}$ & $\mathbf{O}$ & Total & Inference Phases \\
\hline 1 & 61.01 & 36.18 & 2.81 & 100.00 & $\mathrm{Al}_{3} \mathrm{Mg}_{2}$ \\
2 & 90.44 & 0.98 & 8.58 & 100.00 & $\mathrm{Al}_{\text {matrix }}+\mathrm{Al}_{2} \mathrm{O}_{3}$ \\
3 & 44.38 & 19.42 & 36.20 & 100.00 & $\mathrm{Al}_{12} \mathrm{Mg}_{17}+\mathrm{Al}_{2} \mathrm{O}_{3}+\mathrm{MgO}$ \\
\hline
\end{tabular}

Figure 5 demonstrates the representative microstructures and EDS line-scan results of the $\mathrm{Al} / \mathrm{Zr} / \mathrm{Mg}$ joint. As shown in Figure 5a, the smashed $\mathrm{Zr}$ interlayer distributed in the SZ was intermixed with the base materials, while the undamaged part remained stable at the $\mathrm{Al} / \mathrm{Mg}$ interface. The magnified view of the $\mathrm{R} 4$ region in Figure $5 \mathrm{~b}$ displayed three different morphologies of white plates, dark strips, and gray matrix in the SZ. The elemental compositions at points 4-6 in Figure 5b are summarized in Table 3. The white plates, dark strips, and gray matrix marked as points 4, 5, and 6 are $\mathrm{Zr}$ with little $\mathrm{ZrO}_{2}, \mathrm{Al}$ matrix with a lot of $\mathrm{Al}_{2} \mathrm{O}_{3}$ and $\mathrm{MgO}, \mathrm{Al}$ matrix with little $\mathrm{Al}_{2} \mathrm{O}_{3}$, respectively. The magnified view of the $\mathrm{R} 5$ region in Figure $5 \mathrm{c}$ indicates the existence of a thin transition zone at the Mg alloy/SZ interface. The corresponding EDS line-scan results in Figure 5d exhibit a smooth transition in $\mathrm{Al}$ and $\mathrm{Mg}$ content with no abrupt changes from the $\mathrm{Mg}$ alloy to the SZ. 
In comparison with the $\mathrm{Al} / \mathrm{Mg}$ joint (see Figure 4 and Table 2), the $\mathrm{Al} / \mathrm{Zr} / \mathrm{Mg}$ joint revealed more favorable elemental distributions with reduced Al-Mg IMCs (see Figure 5 and Table 3). This microstructure improvement may be explained by the synergetic effects of the $\mathrm{Zr}$ interlayer: (1) The smashed Zr intermixed in the SZ exhibited a chemical modification effect to hinder the strong reaction between the base materials, as evidenced by the much lower $\mathrm{Mg}$ content in the $\mathrm{R} 4$ region than that in the $\mathrm{R} 1$ region; and (2) the undamaged $\mathrm{Zr}$ at the $\mathrm{Al} / \mathrm{Mg}$ interface segregated the contact of the base materials, which showed a thermal barrier effect in mitigating the mutual diffusion of $\mathrm{Al}$ and $\mathrm{Mg}$.
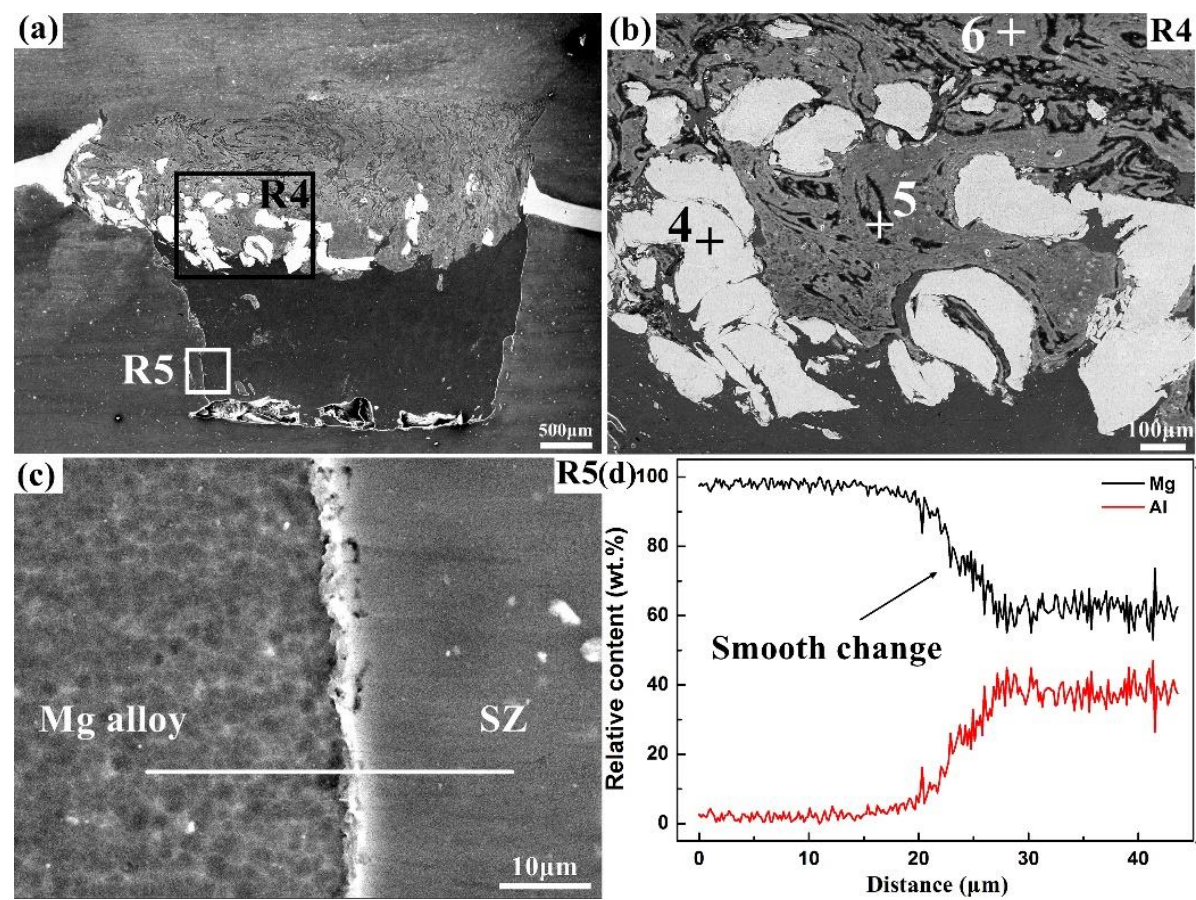

Figure 5. Representative microstructures of the $\mathrm{Al} / \mathrm{Zr} / \mathrm{Mg}$ joint: (a) overview of the stir zone (SZ), $(\mathbf{b}, \mathbf{c})$ magnified views of the R4 and R5, respectively, and (d) EDS line-scan results of the R4.

Table 3. Elemental compositions (in wt.\%) at points 4-6 in Figure 5b.

\begin{tabular}{ccccccc}
\hline Points & $\mathbf{A l}$ & $\mathbf{M g}$ & $\mathbf{O}$ & $\mathbf{Z r}$ & Total & Inference Phases \\
\hline 4 & - & - & 7.38 & 92.62 & 100.00 & $\mathrm{Zr}+\mathrm{ZrO}_{2}$ \\
5 & 64.16 & 8.03 & 27.81 & - & 100.00 & $\mathrm{Al}$ matrix $+\mathrm{Al}_{2} \mathrm{O}_{3}+\mathrm{MgO}$ \\
6 & 92.41 & 1.05 & 6.54 & - & 100.00 & $\mathrm{Al}$ matrix $+\mathrm{Al}_{2} \mathrm{O}_{3}$ \\
\hline
\end{tabular}

\subsection{Corrosion Behavior}

Figure 6 presents the OCP curves for the representative regions of the $\mathrm{Al} / \mathrm{Mg}$ and $\mathrm{Al} / \mathrm{Zr} / \mathrm{Mg}$ joints in the $3.5 \% \mathrm{NaCl}$ solution. The OCP curves of the experimental samples exhibited a rising trend at the initial stage and then became steady at the final stage, indicating that the chemical status on the surface gradually became stable with the increasing immersion time. The highest and lowest OCP values can be found for the $\mathrm{Al}$ alloy and $\mathrm{Mg}$ alloy, respectively. The OCP values of the $\mathrm{Al} / \mathrm{Mg}-\mathrm{HAZ}$, $\mathrm{Al} / \mathrm{Mg}-\mathrm{SZ}, \mathrm{Al} / \mathrm{Zr} / \mathrm{Mg}-\mathrm{HAZ}$, and $\mathrm{Al} / \mathrm{Zr} / \mathrm{Mg}-\mathrm{SZ}$ samples were within the range of the base materials. This variation in OCP values may be related to the passivation layers on the surface. The compact $\mathrm{Al}_{2} \mathrm{O}_{3}$ layer on the $\mathrm{Al}$ alloy surface had some anti-corrosion ability, while the porous $\mathrm{MgO}$ layer on the $\mathrm{Mg}$ alloy surface was easily dissolved by the corrosive media. The passivation layers of the representative regions (HAZ and SZ) were composed of metallic oxide mixtures, such as $\mathrm{Al}_{2} \mathrm{O}_{3}, \mathrm{MgO}$, and $\mathrm{ZrO}_{2}$, which presented a mediate passivation effect. Moreover, there appeared to be some fluctuations 
in the OCP curves, which were caused by the dissolution-regeneration process of the passivation layers [30].

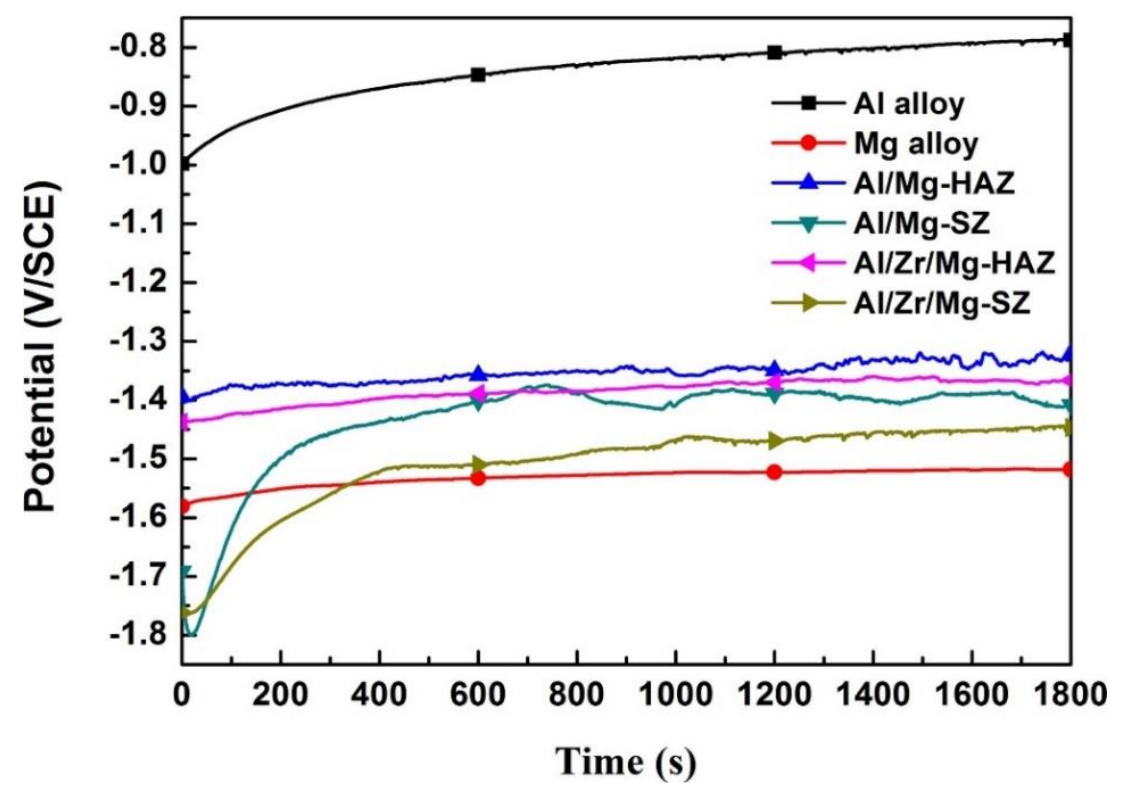

Figure 6. The open circuit potential (OCP) curves for the representative regions of the $\mathrm{Al} / \mathrm{Mg}$ and $\mathrm{Al} / \mathrm{Zr} / \mathrm{Mg}$ joints in the $3.5 \% \mathrm{NaCl}$ solution.

Figure 7 displays the potentiodynamic polarization curves for the representative regions of the $\mathrm{Al} / \mathrm{Mg}$ and $\mathrm{Al} / \mathrm{Zr} / \mathrm{Mg}$ joints in the $3.5 \% \mathrm{NaCl}$ solution. The corresponding electrochemical parameters of $\mathrm{E}_{\mathrm{corr}}$ and $i_{\text {corr }}$ are listed in Table 4 . Usually, the $\mathrm{E}_{\mathrm{corr}}$ is a thermodynamic indicator to estimate the corrosion probability, and a larger $\mathrm{E}_{\mathrm{corr}}$ represents a higher surface stability. On the other hand, the $i_{\text {corr }}$ is a kinetic indicator to evaluate the corrosion degree once corrosion occurs, and a smaller $i_{\text {corr }}$ indicates a lower corrosion rate [31,32]. The $\mathrm{Al}$ alloy had a higher $\mathrm{E}_{\text {corr }}$ and a lower $i_{\text {corr }}$ compared with the $\mathrm{Mg}$ alloy, suggesting that superior corrosion resistance was found for the $\mathrm{Al}$ alloy. The $\mathrm{E}_{\mathrm{corr}}$ of the $\mathrm{Al} / \mathrm{Mg}-\mathrm{HAZ}, \mathrm{Al} / \mathrm{Mg}-\mathrm{SZ}, \mathrm{Al} / \mathrm{Zr} / \mathrm{Mg}-\mathrm{HAZ}$, and $\mathrm{Al} / \mathrm{Zr} / \mathrm{Mg}-\mathrm{SZ}$ samples were between those of the $\mathrm{Al}$ alloy and the $\mathrm{Mg}$ alloy, which were the mixed potentials of the base materials. The $i_{\text {corr }}$ increased in the order of $\mathrm{Al}$ alloy $<\mathrm{Mg}$ alloy $<\mathrm{Al} / \mathrm{Zr} / \mathrm{Mg}-\mathrm{HAZ}<\mathrm{Al} / \mathrm{Mg}-\mathrm{HAZ}<\mathrm{Al} / \mathrm{Zr} / \mathrm{Mg}-\mathrm{SZ}<\mathrm{Al} / \mathrm{Mg}-\mathrm{SZ}$ samples, implying the same change trend in the corrosion rate. For both $\mathrm{Al} / \mathrm{Mg}$ and $\mathrm{Al} / \mathrm{Zr} / \mathrm{Mg}$ joints, the corrosion rate of the representative regions decreased in the order of $\mathrm{SZ}>\mathrm{HAZ}>$ base materials. This phenomenon may have been owing to the following two reasons: (1) The SZ and $\mathrm{HAZ}$, incorporating $\mathrm{Al}$ and $\mathrm{Mg}$ dissimilar alloys, experienced galvanic corrosion at the $\mathrm{Al} / \mathrm{Mg}$ interface because of the potential differences, which induced faster corrosion than the base materials; and (2) different from the HAZ, the SZ possessed a more complex microstructure with heterogeneous phases of Al-Mg IMCs, metals, and metallic oxides, which accelerated the corrosion rate via building more local corrosion cells. In addition, the corrosion behavior of the $\mathrm{Al} / \mathrm{Mg}$ joint was improved by the $\mathrm{Zr}$ interlayer, as could be seen from the smaller $i_{\text {corr }}$ at the $\mathrm{HAZ}$ and $\mathrm{SZ}$ for the $\mathrm{Al} / \mathrm{Zr} / \mathrm{Mg}$ joint. The $\mathrm{Zr}$ interlayer reduced the formation of Al-Mg IMCs in the SZ and segregates the contact of the base materials at the interface (see Figure 5 and Table 3), which mitigated the galvanic corrosion effect between the $\mathrm{Al}$ and $\mathrm{Mg}$ alloys. 


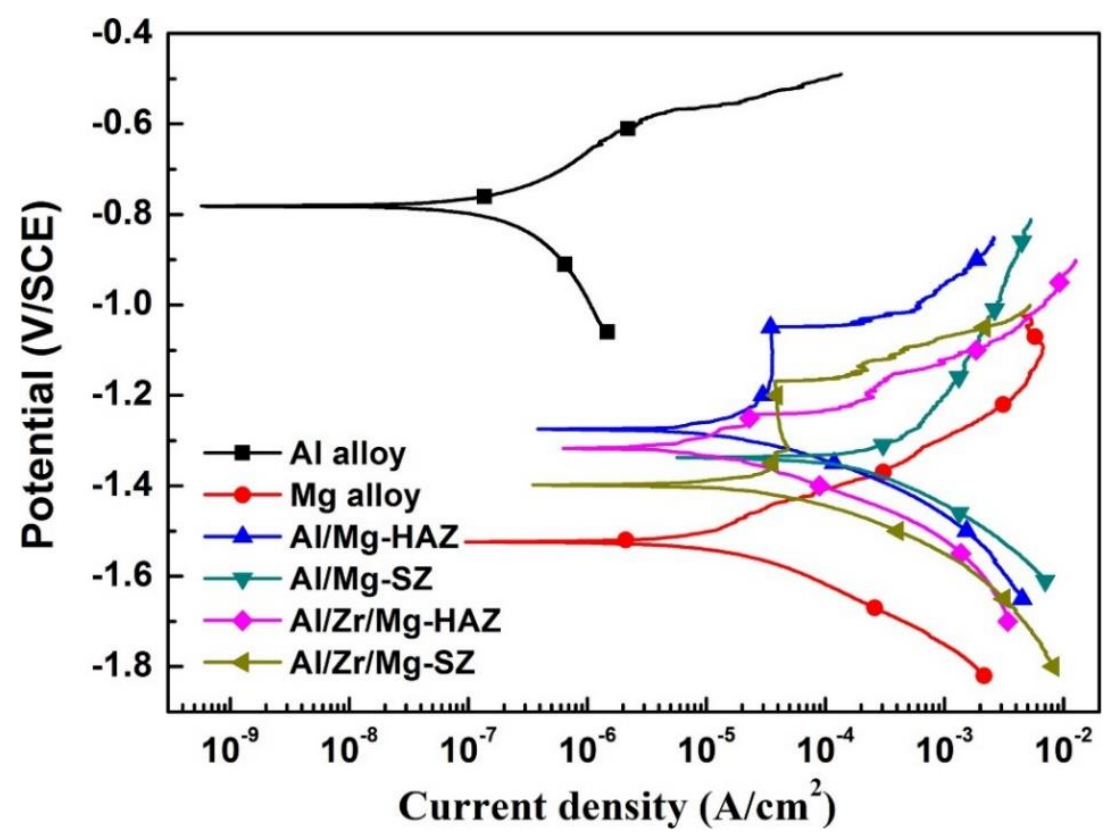

Figure 7. Potentiodynamic polarization curves for the representative regions of the $\mathrm{Al} / \mathrm{Mg}$ and $\mathrm{Al} / \mathrm{Zr} / \mathrm{Mg}$ joints in the $3.5 \% \mathrm{NaCl}$ solution.

Table 4. Electrochemical parameters fitted from the potentiodynamic polarization curves.

\begin{tabular}{ccccccc}
\hline Samples & Al Alloy & Mg Alloy & Al/Mg-HAZ & Al/Mg-SZ & Al/Zr/Mg-HAZ & Al/Zr/Mg-SZ \\
\hline $\mathrm{E}_{\text {corr }}(\mathrm{V} / \mathrm{SCE})$ & $-0.77 \pm 0.01$ & $-1.51 \pm 0.02$ & $-1.27 \pm 0.03$ & $-1.36 \pm 0.02$ & $-1.31 \pm 0.01$ & $-1.43 \pm 0.03$ \\
$i_{\text {corr }}\left(\mu \mathrm{A} / \mathrm{cm}^{2}\right)$ & $0.23 \pm 0.03$ & $12.41 \pm 1.66$ & $29.30 \pm 2.95$ & $320.50 \pm 22.10$ & $13.92 \pm 1.50$ & $60.18 \pm 2.95$ \\
\hline
\end{tabular}

Figure 8 shows the corrosion morphologies of the $\mathrm{Al} / \mathrm{Mg}$ joint after immersion in the $3.5 \% \mathrm{NaCl}$ solution for $4 \mathrm{~h}$. The corresponding elemental compositions of points 7-11 are summarized in Table 5 . It must be pointed out that SEM-EDS is a semi-quantitative measuring technique, and it may cause deviations in quantifying the minor elements. In order to reduce this inaccuracy, the contents of minor elements $(\mathrm{Cl}, \mathrm{Si}$, and $\mathrm{Zn})$ are added up and listed as the "others". The corrosion behavior of the joints were analyzed by comparing the contents of the major elements $(\mathrm{Al}, \mathrm{Mg}, \mathrm{O}$, and $\mathrm{Zr}$ ). This similar analysis method has also been reported in [29], where the phase constitutions of $\mathrm{Al} / \mathrm{Mg}$ dissimilar FSW joints were investigated via the major elements ( $\mathrm{Al}$ and $\mathrm{Mg}$ ) with the minor elements (Fe, Mn, Si, Zn, etc.) added as a whole. As shown Figure 8a, the Al/Mg joint was corroded to form diverse corrosion morphologies at different regions. The magnified view of the R6 region in Figure $8 \mathrm{~b}$ indicates that the $\mathrm{Al}$ alloy with a flat surface had a higher corrosion resistance than the $\mathrm{Mg}$ alloy with a rough surface, which was due to the galvanic corrosion between active $\mathrm{Mg}$ and noble $\mathrm{Al}$ [15]. The corrosion products at the $\mathrm{Al} / \mathrm{Mg}$ interface (point 7) were mainly composed of $\mathrm{O}$ and $\mathrm{Mg}$ with a small amount of $\mathrm{Al}$, implying the formation of $\mathrm{Mg}$ oxides. The corroded surface of the $\mathrm{Mg}$ alloy (point 8) was filled with blocky corrosion products, whose composition had slightly lower $\mathrm{Al}$ and $\mathrm{O}$ with higher $\mathrm{Mg}$ compared with the $\mathrm{Al} / \mathrm{Mg}$ interface (point 7). The magnified view of the $\mathrm{R7}$ region in Figure $8 \mathrm{c}$ is featured with two distinct corrosion forms: the uniform corrosion at the Al alloy (point 9) and the discrete corrosion on the top of the SZ (point 10). The granular corrosion morphology at point 9 contained $60.01 \mathrm{Al}, 4.85 \mathrm{Mg}, 29.46 \mathrm{O}$, and 5.68 minor elements (in wt.\%) due to the corrosion of the $\mathrm{Al}$ alloy, while the dendritic corrosion morphology at point 10 included $49.85 \mathrm{Al}, 31.27 \mathrm{Mg}, 17.28 \mathrm{O}$, and 1.60 minor elements (in wt.\%), owing to the combined corrosion of the base materials and Al-Mg IMCs. The magnified view of the R8 region in Figure $8 \mathrm{~d}$ demonstrates that the SZ on the bottom had a compact corrosion morphology, whereas the adjacent $\mathrm{Mg}$ alloy was badly corroded to form many 
cracks and some holes. High $\mathrm{O}$ and $\mathrm{Mg}$ with trace $\mathrm{Al}$ were detected on the bottom of the SZ (point 11), suggesting the existence of $\mathrm{Mg}$ oxides formed by the corrosion of the Mg alloy.
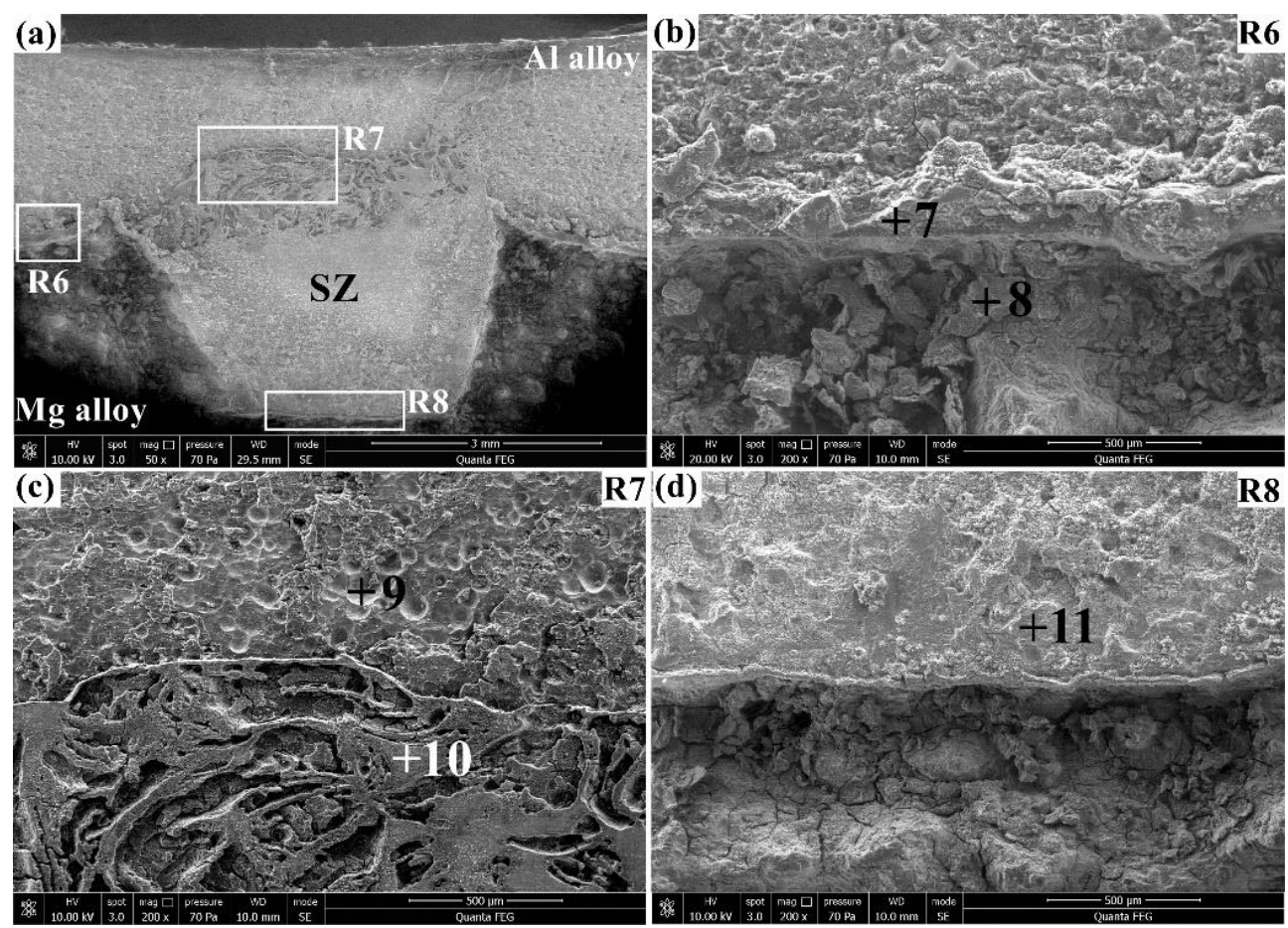

Figure 8. Corrosion morphologies of the $\mathrm{Al} / \mathrm{Mg}$ joint in the $3.5 \% \mathrm{NaCl}$ solution for $4 \mathrm{~h}$ : (a) overview and (b-d) magnified views of the R6, R7, and R8, respectively.

Table 5. Elemental compositions (in wt.\%) of points 7-11 in Figure 8b-d.

\begin{tabular}{cccccc}
\hline Points & Al & Mg & O & Others & Total \\
\hline 7 & 8.54 & 30.31 & 56.91 & 4.24 & 100.00 \\
8 & 2.81 & 34.80 & 52.45 & 9.94 & 100.00 \\
9 & 60.01 & 4.85 & 29.46 & 5.68 & 100.00 \\
10 & 49.85 & 31.27 & 17.28 & 1.60 & 100.00 \\
11 & 0.73 & 43.71 & 53.78 & 1.78 & 100.00 \\
\hline
\end{tabular}

The corrosion morphologies of the $\mathrm{Al} / \mathrm{Zr} / \mathrm{Mg}$ joint after immersion in the $3.5 \% \mathrm{NaCl}$ solution for $4 \mathrm{~h}$ are exhibited in Figure 9. Table 6 lists the corresponding elemental compositions of points 12-17. In Figure 9a, an inhomogeneous corrosion morphology can be observed for the $\mathrm{Al} / \mathrm{Zr} / \mathrm{Mg}$ joint with the appearance of some $\mathrm{Zr}$ pieces. The magnified view of the R9 region in Figure $9 \mathrm{~b}$ shows a sandwiched microstructure with the $\mathrm{Al}$ and $\mathrm{Mg}$ alloys being separated by the $\mathrm{Zr}$ interlayer, which blocks the contact of the base materials and retards the galvanic corrosion at the $\mathrm{Al} / \mathrm{Mg}$ interface to some degree. The corroded surface of the $\mathrm{Zr}$ interlayer (point 12) was characterized by high $\mathrm{O}$ and $\mathrm{Zr}$ with some $\mathrm{Al}$ and $\mathrm{Mg}$, indicating that the main corrosion products were $\mathrm{Zr}$ oxides. The blocky corrosion products of the $\mathrm{Mg}$ alloy (point 13) have higher $\mathrm{Mg}$ and comparable $\mathrm{Al}$ and $\mathrm{O}$ compared with point 8 (see Figure $8 \mathrm{~b}$ ), implying that the corrosion of the $\mathrm{Mg}$ alloy was slightly mitigated. The magnified view of the R10 region in Figure 9c presents a corrosion morphology similar to that of the $\mathrm{R} 7$ region of the $\mathrm{Al} / \mathrm{Mg}$ joint. The corrosion products of the $\mathrm{Al}$ alloy at point 14 were composed of $81.37 \mathrm{Al}, 1.89 \mathrm{Mg}, 14.53 \mathrm{O}$, and 2.21 minor elements (in wt.\%), indicating that a lower corrosion degree than point 9 (see Figure 8c) was obtained. The corroded surface on the top of the SZ (point 15) showed a relatively uniform and continuous corrosion morphology with comparable compositions of $47.39 \mathrm{Al}, 29.43 \mathrm{Mg}, 22.29 \mathrm{O}$, and 0.89 minor elements (in wt.\%) to those of point 10 (see Figure 8c). The magnified view of the R11 region in Figure 9d shows that many irregular Zr pieces were embedded 
in the middle of the SZ, whose composition primarily consisted of $\mathrm{Zr}$ and $\mathrm{O}$ with little $\mathrm{Al}$ and $\mathrm{Mg}$ (point 16). The magnified view of the R12 region in Figure 9e exhibits a corrosion morphology similar to that of the $\mathrm{R} 8$ region of the $\mathrm{Al} / \mathrm{Mg}$ joint. The corrosion degree of the SZ on the bottom (Point 17) was comparable to that of point 11 (see Figure $8 d$ ), as can be seen by their similar compositions.

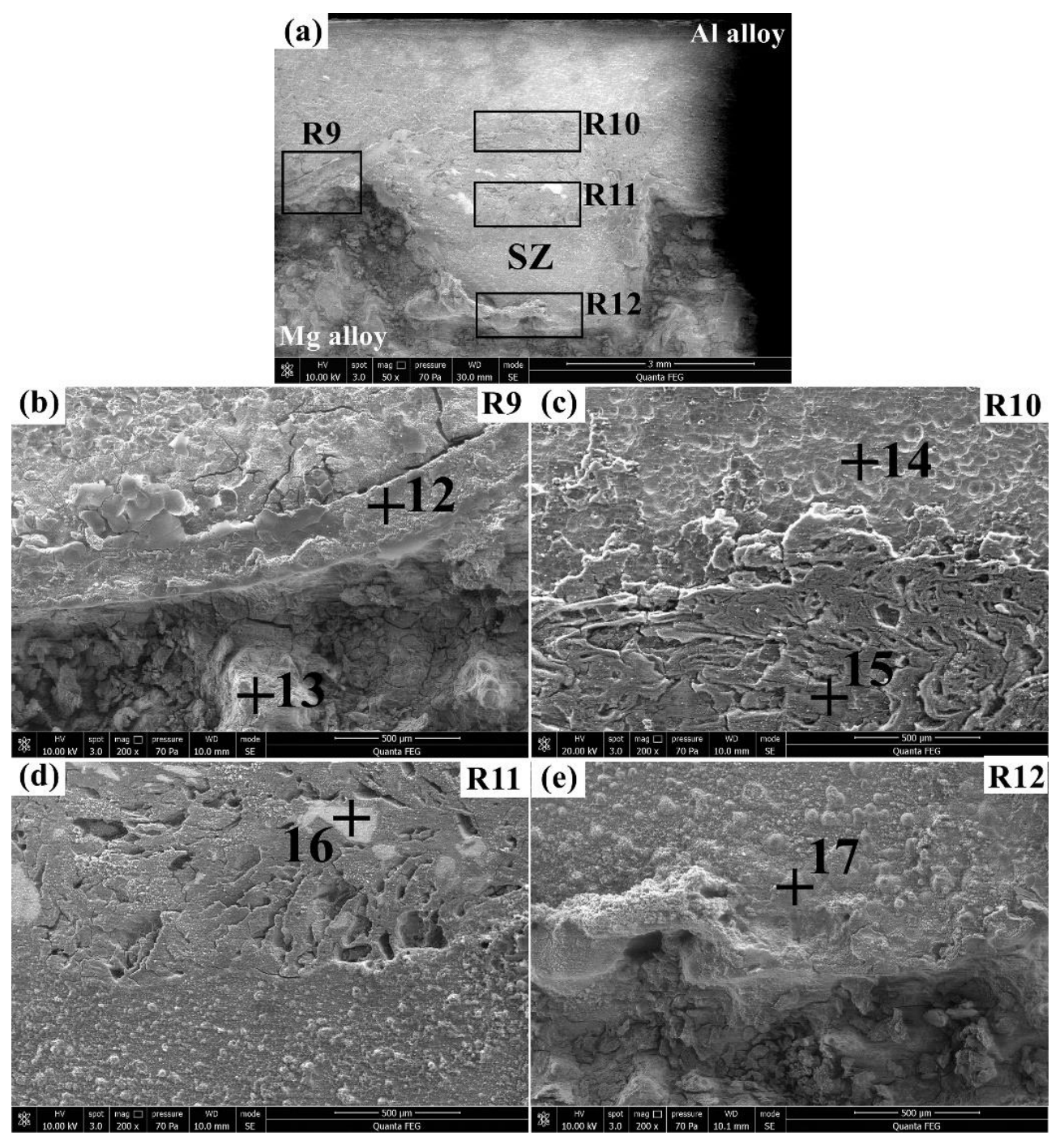

Figure 9. Corrosion morphologies of the $\mathrm{Al} / \mathrm{Zr} / \mathrm{Mg}$ joint in the $3.5 \% \mathrm{NaCl}$ solution for $4 \mathrm{~h}$ : (a) overview and (b-e) magnified views of the R9, R10, R11, and R12, respectively.

Table 6. Elemental compositions (in wt.\%) of points 12-17 in Figure 9b-e.

\begin{tabular}{ccccccc}
\hline Points & $\mathbf{A l}$ & $\mathbf{M g}$ & $\mathbf{O}$ & $\mathbf{Z r}$ & Others & Total \\
\hline 12 & 3.35 & 10.32 & 50.70 & 35.03 & 0.60 & 100.00 \\
13 & 2.62 & 40.64 & 54.69 & - & 2.05 & 100.00 \\
14 & 81.37 & 1.89 & 14.53 & - & 2.21 & 100.00 \\
15 & 47.39 & 29.43 & 22.29 & - & 0.89 & 100.00 \\
16 & 3.19 & 3.91 & 34.72 & 57.16 & 1.02 & 100.00 \\
17 & 2.56 & 44.31 & 53.13 & - & - & 100.00 \\
\hline
\end{tabular}

Figure 10 displays the corrosion morphologies of the $\mathrm{Al} / \mathrm{Mg}$ joint after immersion in the $3.5 \%$ $\mathrm{NaCl}$ solution for $60 \mathrm{~h}$. The corresponding elemental compositions of points 18-20 are listed in Table 7 . As shown in Figure 10a, the corrosion degree of the $\mathrm{Al} / \mathrm{Mg}$ joint was aggravated as the immersion time increased to $60 \mathrm{~h}$. The magnified view of the R13 region in Figure 10b shows that more severe 
corrosion was found for the $\mathrm{Al}$ and $\mathrm{Mg}$ alloys compared with the $\mathrm{Al} / \mathrm{Mg}$ interface. The corroded surface at the $\mathrm{Al} / \mathrm{Mg}$ interface (point 18) had a similar composition with that of point 7 (see Figure 8b), indicating that no further corrosion was obviously observed at the $\mathrm{Al} / \mathrm{Mg}$ interface as immersion time increased. The magnified view of the R14 region in Figure 10c exhibits a discrete corrosion morphology on the top of the SZ, which produced a discontinuous surface with many irregular grooves. The dendritic corrosion morphology at point 19 had a heavier corrosion degree than point 10 (see Figure 8c), as evidenced by its lower $\mathrm{Al}, \mathrm{Mg}$, and higher $\mathrm{O}$. The magnified view of the R15 region in Figure 10d demonstrates that the $\mathrm{Mg}$ alloy corroded faster than the SZ on the bottom to form an uneven surface with a large height difference. Relatively higher Al and lower Mg were detected on the bottom of the SZ (point 20) than at point 11 (see Figure 8d), which resulted from the further corrosion of the $\mathrm{Mg}$ alloy.
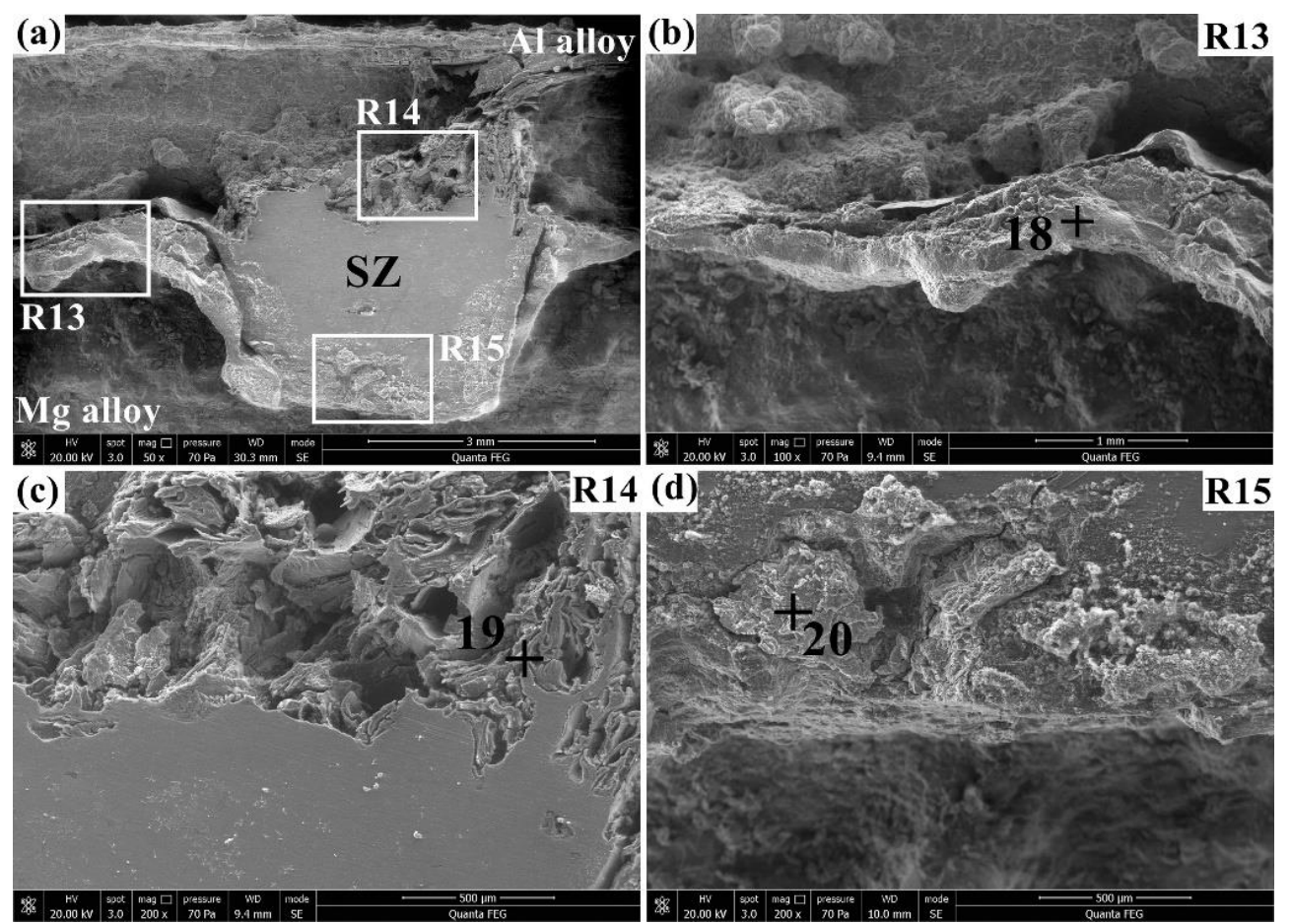

Figure 10. Corrosion morphologies of the $\mathrm{Al} / \mathrm{Mg}$ joint in the $3.5 \% \mathrm{NaCl}$ solution for $60 \mathrm{~h}$ : (a) overview and (b-d) magnified views of the R13, R14, and R15, respectively.

Table 7. Elemental compositions (in wt.\%) of points 18-20 in Figure 10b-d.

\begin{tabular}{cccccc}
\hline Points & Al & Mg & O & Others & Total \\
\hline 18 & 5.29 & 39.42 & 55.29 & - & 100.00 \\
19 & 40.14 & 27.20 & 29.22 & 3.44 & 100.00 \\
20 & 9.62 & 33.13 & 55.63 & 1.62 & 100.00 \\
\hline
\end{tabular}

The corrosion morphologies of the $\mathrm{Al} / \mathrm{Zr} / \mathrm{Mg}$ joint after immersion in the $3.5 \% \mathrm{NaCl}$ solution for $60 \mathrm{~h}$ are presented in Figure 11. Table 8 summarizes the corresponding elemental compositions of points 21-24. As shown in Figure 11a, relatively mild corrosion with a flatter corroded morphology was found in the $\mathrm{Al} / \mathrm{Zr} / \mathrm{Mg}$ joint compared with that of the $\mathrm{Al} / \mathrm{Mg}$ joint after $60 \mathrm{~h}$ of immersion time (see Figure 10a). The magnified view of the R16 region in Figure 11b shows that the Zr interlayer remained stable at the $\mathrm{Al} / \mathrm{Mg}$ interface to balance the corrosion of the base materials, as can be seen from the inconspicuous height difference between the $\mathrm{Al}$ and $\mathrm{Mg}$ alloys. The corroded surface of the $\mathrm{Zr}$ interlayer (point 21) had a higher $\mathrm{Al}$ and $\mathrm{Mg}$ and a much lower $\mathrm{Zr}$ than that at point 12 (see Figure 9b), implying the further corrosion of the $\mathrm{Zr}$ interlayer. The magnified view of the R17 region in Figure 11c 
exhibits that the SZ on the top was corroded to form some small pits with the existence of dendritic corrosion products and $\mathrm{Zr}$ pieces. The dendritic corrosion products at point 22 were characterized by a much lower $\mathrm{Al}$, higher $\mathrm{O}$, and similar $\mathrm{Mg}$ compared with that of point 19 (see Figure 10c), suggesting that the $\mathrm{Al}$ alloy was further corroded to form metallic oxides on the top of the SZ. The $\mathrm{Zr}$ pieces at point 23 had similar compositions with those at point 16 (see Figure 9d), indicating that no further corrosion was observed for the $\mathrm{Zr}$ pieces. The magnified view of the R18 region in Figure $11 \mathrm{~d}$ demonstrates that there was a transverse crevice on the bottom of the SZ, which may have provided passages for corrosive media to further corrosion. The corrosion products on the bottom of the SZ (point 24) had comparable compositions with those at point 20 (see Figure 10d), suggesting a similar corrosion degree for both sites.
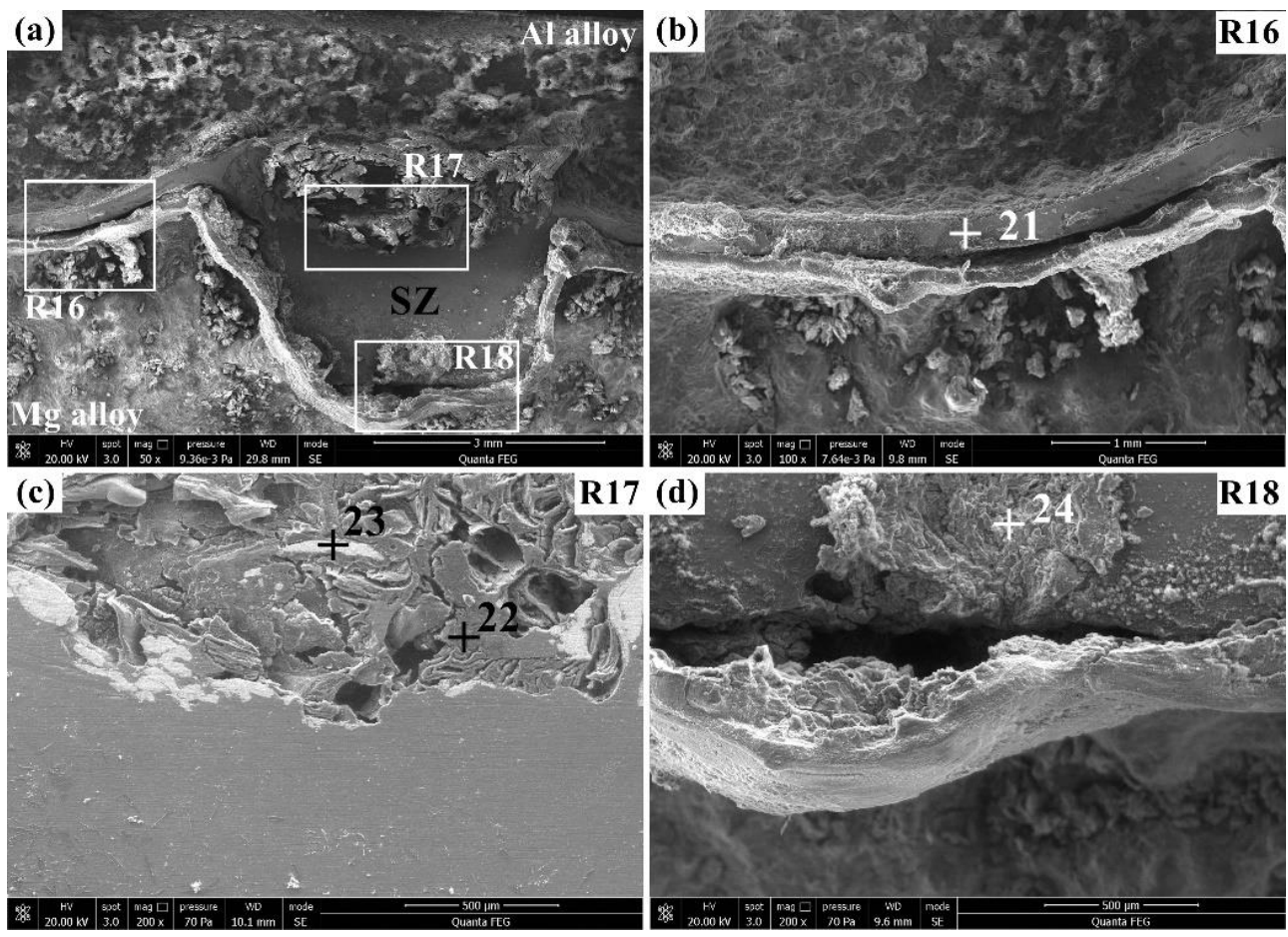

Figure 11. Corrosion morphologies of the $\mathrm{Al} / \mathrm{Zr} / \mathrm{Mg}$ joint in the $3.5 \% \mathrm{NaCl}$ solution for $60 \mathrm{~h}$ : (a) overview and (b-d) magnified views of the R16, R17, and R18, respectively.

Table 8. Elemental compositions (in wt.\%) of points 21-24 in Figure 11b-d.

\begin{tabular}{clccccc}
\hline Points & Al & $\mathbf{M g}$ & $\mathbf{O}$ & $\mathbf{Z r}$ & Others & Total \\
\hline 21 & 20.65 & 18.76 & 58.12 & 1.53 & 0.94 & 100.00 \\
22 & 16.98 & 25.13 & 53.94 & 1.49 & 2.46 & 100.00 \\
23 & 2.30 & 3.76 & 34.45 & 59.49 & - & 100.00 \\
24 & 8.47 & 30.96 & 58.08 & - & 2.49 & 100.00 \\
\hline
\end{tabular}

Figure 12 presents the XRD patterns for the corrosion products of the $\mathrm{Al} / \mathrm{Mg}$ and $\mathrm{Al} / \mathrm{Zr} / \mathrm{Mg}$ joints. No obvious differences in XRD patterns were observed between the $\mathrm{Al} / \mathrm{Mg}$ and $\mathrm{Al} / \mathrm{Zr} / \mathrm{Mg}$ joints, suggesting that the phase constitutions of the corrosion products for both joints were similar. The diffraction peaks of the corrosion products were identified as $\mathrm{Mg}(\mathrm{OH})_{2}, \mathrm{Al}(\mathrm{OH})_{3}$, and $\mathrm{Mg}_{2} \mathrm{Al}(\mathrm{OH})_{7}$ phases by MDI Jade 6.0 software, which correspond to the standard PDF \#83-0114, \#20-0011, and \#35-1275, respectively. The corrosion of Al and $\mathrm{Mg}$ alloys usually produces metallic oxides, which are easily transformed to metallic hydroxides under humid environment [33,34]. Furthermore, no $\mathrm{Zr}$-containing phase was detected because of its low content. The detection of metallic hydroxides 
by the XRD patterns was inconsistent with the EDS results, which was attributed to the inability of EDS to detect $\mathrm{H}$.

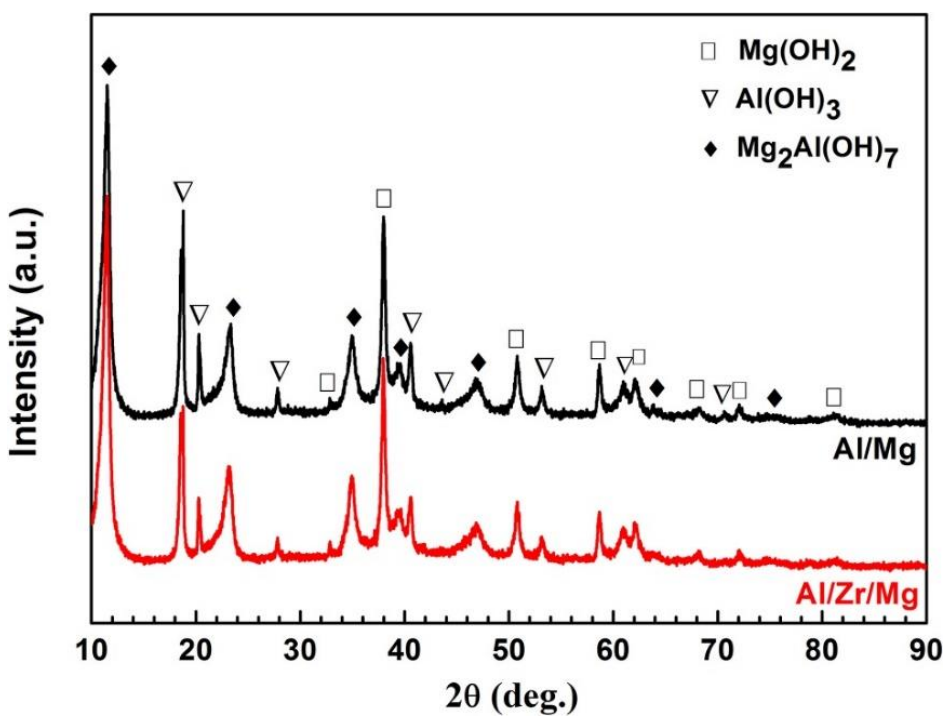

Figure 12. XRD patterns for the corrosion products of the $\mathrm{Al} / \mathrm{Mg}$ and $\mathrm{Al} / \mathrm{Zr} / \mathrm{Mg}$ joints.

Figure 13 illustrates the weight losses and corresponding change rates of the $\mathrm{Al} / \mathrm{Mg}$ and $\mathrm{Al} / \mathrm{Zr} / \mathrm{Mg}$ joints during the immersion tests in the $3.5 \% \mathrm{NaCl}$ solution for $60 \mathrm{~h}$. The weight loss of the $\mathrm{Al} / \mathrm{Mg}$ joint linearly increased to $176.42 \pm 12.22 \mathrm{mg} / \mathrm{cm}^{2}$ in the initial $28 \mathrm{~h}$ and slowly increased to $268.72 \pm 13.44 \mathrm{mg} / \mathrm{cm}^{2}$ in the last $32 \mathrm{~h}$. The weight loss of the $\mathrm{Al} / \mathrm{Zr} / \mathrm{Mg}$ joint reached $231.08 \pm 4.81 \mathrm{mg} / \mathrm{cm}^{2}$ during the whole $60 \mathrm{~h}$ and exhibited a $14 \%$ reduction compared with that of the $\mathrm{Al} / \mathrm{Mg}$ joint, which evidenced that the corrosion resistance was enhanced by the $\mathrm{Zr}$ interlayer. Moreover, the weight loss rate of the $\mathrm{Al} / \mathrm{Mg}$ joint slowly increased to $6.30 \pm 0.44 \mathrm{mg} / \mathrm{cm}^{2} / \mathrm{h}$ with increasing immersion time to $28 \mathrm{~h}$ and then decreased to $4.48 \pm 0.22 \mathrm{mg} / \mathrm{cm}^{2} / \mathrm{h}$ at the end of $60 \mathrm{~h}$. A similar change trend in weight loss rate was found for the $\mathrm{Al} / \mathrm{Zr} / \mathrm{Mg}$ joint except for the slightly lower value at each immersion time. The slowdown in weight loss rate may be attributed to the gradual deposition of corrosion products on the surface, which can act as a protective layer to suppress further corrosion [35].

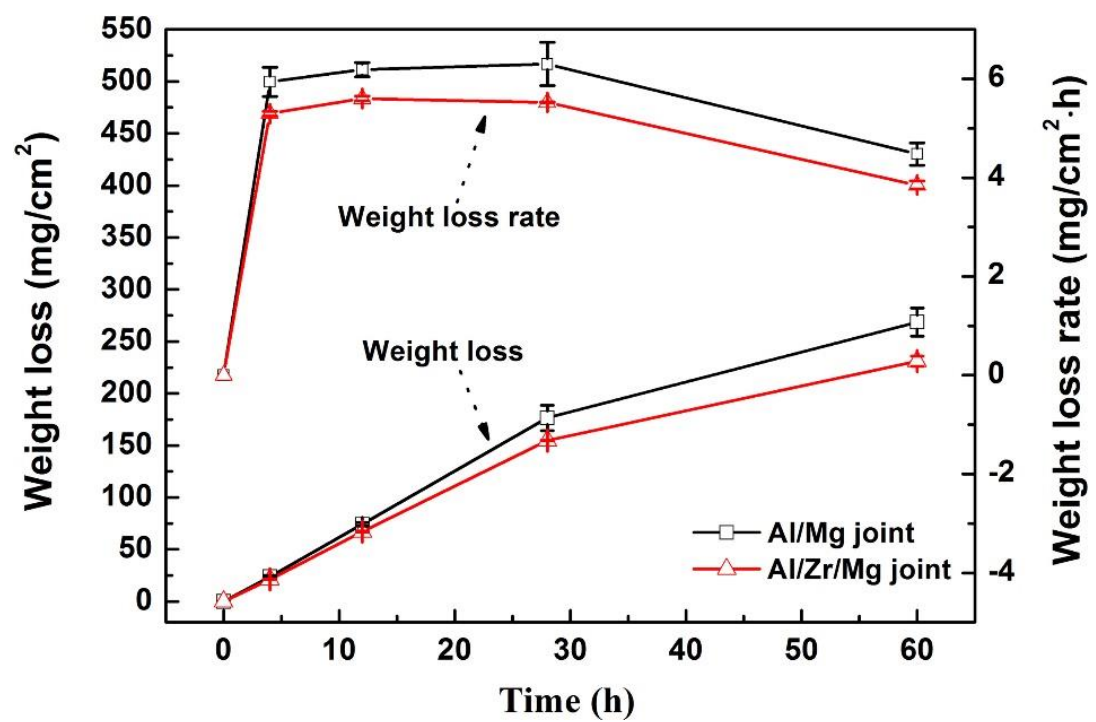

Figure 13. Weight losses and corresponding change rates of the $\mathrm{Al} / \mathrm{Mg}$ and $\mathrm{Al} / \mathrm{Zr} / \mathrm{Mg}$ joints during the immersion tests in the $3.5 \% \mathrm{NaCl}$ solution for $60 \mathrm{~h}$. 


\section{Conclusions}

In this work, the microstructure and corrosion behavior of friction stir-welded $6061 \mathrm{Al} / \mathrm{AZ3} 1 \mathrm{Mg}$ joints with $\mathrm{Zr}$ interlayer were studied. The following conclusions were drawn:

(1) Dissimilar alloys of $6061 \mathrm{Al}$ and AZ31 Mg were successfully joined by FSW with a Zr interlayer. The central part of the $\mathrm{Zr}$ interlayer was smashed and intermixed with the base materials in the SZ, and the undamaged part remained stable at the $\mathrm{Al} / \mathrm{Mg}$ interface. The $\mathrm{Zr}$ interlayer improved the elemental distributions to exhibit reduced Al-Mg IMCs in the SZ and a thinner transition zone at the interface, which was attributed to its chemical modification and thermal barrier effects.

(2) A differentiated corrosion behavior was found for the representative regions of the joints, whose corrosion rate increased in the order of $\mathrm{Al}$ alloy $<\mathrm{Mg}$ alloy $<\mathrm{Al} / \mathrm{Zr} / \mathrm{Mg}-\mathrm{HAZ}<\mathrm{Al} / \mathrm{Mg}-\mathrm{HAZ}<\mathrm{Al} / \mathrm{Zr} / \mathrm{Mg}-\mathrm{SZ}<\mathrm{Al} / \mathrm{Mg}-\mathrm{SZ}$. The SZ with heterogeneous phases of Al-Mg IMCs, metals, and metallic oxides showed a larger corrosion rate than the HAZ for each joint, which was owing to its more local corrosion cells than the HAZ.

(3) The $\mathrm{Zr}$ interlayer enhanced the corrosion resistance of the $\mathrm{Al} / \mathrm{Mg}$ joint to present a $14 \%$ reduction in weight loss for the $\mathrm{Al} / \mathrm{Zr} / \mathrm{Mg}$ joint after immersion tests in the $3.5 \% \mathrm{NaCl}$ solution, which was ascribed to its beneficial effect in mitigating the galvanic corrosion between the base materials. The corrosion products of the $\mathrm{Al} / \mathrm{Mg}$ and $\mathrm{Al} / \mathrm{Zr} / \mathrm{Mg}$ joints were mainly composed of $\mathrm{Mg}(\mathrm{OH})_{2}$, $\mathrm{Al}(\mathrm{OH})_{3}$, and $\mathrm{Mg}_{2} \mathrm{Al}(\mathrm{OH})_{7}$ phases.

Our future work will investigate the relationship between the joint microstructure, corrosion behavior, and mechanical properties under various combinations of FSW parameters and Zr interlayer thicknesses to prepare high-quality $\mathrm{Al} / \mathrm{Mg}$ dissimilar joints.

Author Contributions: Conceptualization, Y.Z.; Investigation, Y.Z., Y.M., X.P., S.L., and L.Z.; Original draft preparation, Y.Z.; Review and editing of manuscript, X.P. and Y.M.; Funding acquisition, Y.Z.; and Supervision, Y.C.

Funding: This work was supported by the Postdoctoral Research Projects Selected Funding of Hebei Province (B2018003005).

Conflicts of Interest: The authors declare no conflict of interest.

\section{References}

1. Meschut, G.; Janzen, V.; Olfermann, T. Innovative and highly productive joining technologies for multi-material lightweight car body structures. J. Mater. Eng. Perform. 2014, 23, 1515-1523. [CrossRef]

2. Liu, X.; Lim, Y.C.; Li, Y.B.; Tang, W.; Ma, Y.W.; Feng, Z.L.; Ni, J. Effects of process parameters on friction self-piercing riveting of dissimilar materials. J. Mater. Process. Technol. 2016, 237, 19-30. [CrossRef]

3. Patel, V.K.; Bhole, S.D.; Chen, D.L. Improving weld strength of magnesium to aluminium dissimilar joints via tin interlayer during ultrasonic spot welding. Sci. Technol. Weld. Join. 2012, 17, 342-347. [CrossRef]

4. Liu, L.M.; Ren, D.X.; Liu, F. A review of dissimilar welding techniques for magnesium alloys to aluminum alloys. Materials 2014, 7, 3735-3757. [CrossRef]

5. Rao, H.M.; Ghaffari, B.; Yuan, W.; Jordon, J.B.; Badarinarayan, H. Effect of process parameters on microstructure and mechanical behaviors of friction stir linear welded aluminum to magnesium. Mater. Sci. Eng. A 2016, 651, 27-36. [CrossRef]

6. Dorbane, A.; Mansoor, B.; Ayoub, G.; Shunmugasamy, V.C.; Imad, A. Mechanical, microstructural and fracture properties of dissimilar welds produced by friction stir welding of AZ31B and Al6061. Mater. Sci. Eng. A 2016, 651, 720-733. [CrossRef]

7. Sato, Y.S.; Park, S.H.C.; Michiuchi, M.; Kokawa, H. Constitutional liquation during dissimilar friction stir welding of $\mathrm{Al}$ and Mg alloys. Scr. Mater. 2004, 50, 1233-1236. [CrossRef]

8. Kostka, A.; Coelho, R.S.; Santos, J.D.; Pyzalla, A.R. Microstructure of friction stir welding of aluminium alloy to magnesium alloy. Scr. Mater. 2009, 60, 953-956. [CrossRef] 
9. Chowdhury, S.H.; Chen, D.L.; Bhole, S.D.; Cao, X.; Wanjara, P. Lap shear strength and fatigue behavior of friction stir spot welded dissimilar magnesium-to-aluminum joints with adhesive. Mater. Sci. Eng. A 2013, 562, 53-60. [CrossRef]

10. Xu, R.Z.; Ni, D.R.; Yang, Q.; Liu, C.Z.; Ma, Z.Y. Influence of Zn coating on friction stir spot welded magnesium-aluminum joint. Sci. Technol. Weld. Join. 2017, 22, 512-519. [CrossRef]

11. Wang, Y.; Zubaidy, B.A.; Prangnell, P.B. The effectiveness of Al-Si coatings for preventing interfacial reaction in Al-Mg dissimilar metal welding. Metall. Mater. Trans. A 2018, 49, 162-176. [CrossRef]

12. Gao, Y.; Morisada, Y.; Fujii, H.; Liao, J. Dissimilar friction stir lap welding of magnesium to aluminum using plasma electrolytic oxidation interlayer. Mater. Sci. Eng. A 2018, 711, 109-118. [CrossRef]

13. Savguira, Y.; North, T.H.; Thorpe, S.J. Corrosion mechanisms in dissimilar AZ31/ AZ80 friction stir welds. J. Electrochem. Soc. 2018, 165, C1-C10. [CrossRef]

14. Wu, P.F.; Deng, Y.L.; Fan, S.T.; Ji, H.; Zhang, X.M. A study on dissimilar friction stir welded between the $\mathrm{Al}-\mathrm{Li}-\mathrm{Cu}$ and the $\mathrm{Al}-\mathrm{Zn}-\mathrm{Mg}-\mathrm{Cu}$ alloys. Materials 2018, 11, 1132. [CrossRef] [PubMed]

15. Liu, C.; Chen, D.L.; Bhole, S.; Cao, X.; Jahazi, M. Polishing-assisted galvanic corrosion in the dissimilar friction stir welded joint of AZ31 magnesium alloy to 2024 aluminum alloy. Mater. Charact. 2009, 60, 370-376. [CrossRef]

16. Li, S.X.; Khan, H.; Hihara, L.H.; Li, J.J. Marine atmospheric corrosion of Al-Mg joints by friction stir blind riveting. Corros. Sci. 2016, 111, 793-801. [CrossRef]

17. Dong, J.L.; Zhang, D.T.; Zhang, W.W.; Zhang, W.; Qiu, C. Microstructure evolution during dissimilar friction stir welding of AA7003-T4 and AA6060-T4. Materials 2018, 11, 342. [CrossRef] [PubMed]

18. Vacchi, G.S.; Plaine, A.H.; Silva, R.; Sordi, V.L.; Suhuddin, U.F.H.; Alcântara, N.G.; Kuri, S.E.; Rovere, C.A.D. Effect of friction spot welding (FSpW) on the surface corrosion behavior of overlapping AA6181-T4/Ti-6Al-4V joints. Mater. Des. 2017, 131, 127-134. [CrossRef]

19. Davoodi, A.; Esfahani, Z.; Sarvghad, M. Microstructure and corrosion characterization of the interfacial region in dissimilar friction stir welded AA5083 to AA7023. Corros. Sci. 2016, 107, 133-144. [CrossRef]

20. Kim, Y.G.; Fujii, H.; Tsumura, T.; Komazaki, T.; Nakata, K. Three defect types in friction stir welding of aluminum die casting alloy. Mater. Sci. Eng. A 2006, 415, 250-254. [CrossRef]

21. Li, Z.W.; Yue, Y.M.; Ji, S.D.; Chai, P.; Zhou, Z.L. Joint features and mechanical properties of friction stir lap welded alclad 2024 aluminum alloy assisted by external stationary shoulder. Mater. Des. 2016, 90, 238-247. [CrossRef]

22. Mohammadi, J.; Behnamian, Y.; Mostafaei, A.; Gerlich, A.P. Tool geometry, rotation and travel speeds effects on the properties of dissimilar magnesium/aluminum friction stir welded lap joints. Mater. Des. 2015, 75, 95-112. [CrossRef]

23. Crawford, R.; Cook, G.E.; Strauss, A.M.; Hartman, D.A.; Stremler, M.A. Experimental defect analysis and force prediction simulation of high weld pitch friction stir welding. Sci. Technol. Weld. Join. 2006, 11, 657-665. [CrossRef]

24. Fu, B.L.; Qin, G.L.; Li, F.; Meng, X.M.; Zhang, J.Z.; Wu, C.S. Friction stir welding process of dissimilar metals of 6061-T6 aluminum alloy to AZ31B magnesium alloy. J. Mater. Process. Technol. 2015, 218, 38-47. [CrossRef]

25. Lv, X.Q.; Wu, C.S.; Padhy, G.K. Diminishing intermetallic compound layer in ultrasonic vibration enhanced friction stir welding of aluminum alloy to magnesium alloy. Mater. Lett. 2017, 203, 81-84. [CrossRef]

26. Firouzdor, V.; Kou, S. Formation of liquid and intermetallics in Al-to-Mg friction stir welding. Metall. Mater. Trans. A 2010, 41, 3238-3251. [CrossRef]

27. Suhuddin, U.F.H.; Fischer, V.; Santos, J.F.D. The thermal cycle during the dissimilar friction spot welding of aluminum and magnesium alloy. Scr. Mater. 2013, 68, 87-90. [CrossRef]

28. Mohammadi, J.; Behnamian, Y.; Mostafaei, A.; Izadi, H.; Saeid, T.; Kokabi, A.H.; Gerlich, A.P. Friction stir welding joint of dissimilar materials between AZ31B magnesium and 6061 aluminum alloys: Microstructure studies and mechanical characterizations. Mater. Charact. 2015, 101, 189-207. [CrossRef]

29. Shi, H.; Chen, K.; Liang, Z.Y.; Dong, F.B.; Yu, T.W.; Dong, X.P.; Zhang, L.T.; Shan, A.D. Intermetallic compounds in the banded structure and their effect on mechanical properties of $\mathrm{Al} / \mathrm{Mg}$ dissimilar friction stir welding joints. J. Mater. Sci. Technol. 2017, 33, 359-366. [CrossRef]

30. Zheng, Y.; Zang, L.B.; Bi, Y.Z.; Li, Y.; Chen, Y. Corrosion behavior of Fe/Zr composite coating on ZK60 Mg alloy by ion implantation and deposition. Coatings 2018, 8, 261. [CrossRef] 
31. Zhao, T.T.; Li, Y.; Xiang, Y.; Zhao, X.; Zhang, T. Surface characteristics, nano-indentation and corrosion behavior of $\mathrm{Nb}$ implanted NiTi alloy. Surf. Coat. Technol. 2011, 205, 4404-4410. [CrossRef]

32. Zheng, Y.; Li, Y.; Chen, J.H.; Zou, Z.Y. Effects of tensile and compressive deformation on corrosion behavior of a Mg-Zn alloy. Corros. Sci. 2015, 90, 445-450. [CrossRef]

33. Liu, Y.J.; Wang, Z.Y.; Ke, W. Study on influence of native oxide and corrosion products on atmospheric corrosion of pure Al. Corros. Sci. 2014, 80, 169-176. [CrossRef]

34. Yang, L.J.; Wei, Y.H.; Hou, L.F.; Zhang, D. Corrosion behavior of die-cast AZ91D magnesium alloy in aqueous sulphate solutions. Corros. Sci. 2010, 52, 345-351. [CrossRef]

35. Zhang, S.Y.; Zheng, Y.; Zhang, L.M.; Bi, Y.Z.; Li, J.Y.; Liu, J.; Yu, Y.B.; Guo, H.Q.; Li, Y. In vitro and in vivo corrosion and histocompatibility of pure $\mathrm{Mg}$ and a $\mathrm{Mg}-6 \mathrm{Zn}$ alloy as urinary implants in rat model. Mater. Sci. Eng. C 2016, 68, 414-422. [CrossRef] [PubMed]

2019 by the authors. Licensee MDPI, Basel, Switzerland. This article is an open access article distributed under the terms and conditions of the Creative Commons Attribution (CC BY) license (http://creativecommons.org/licenses/by/4.0/). 